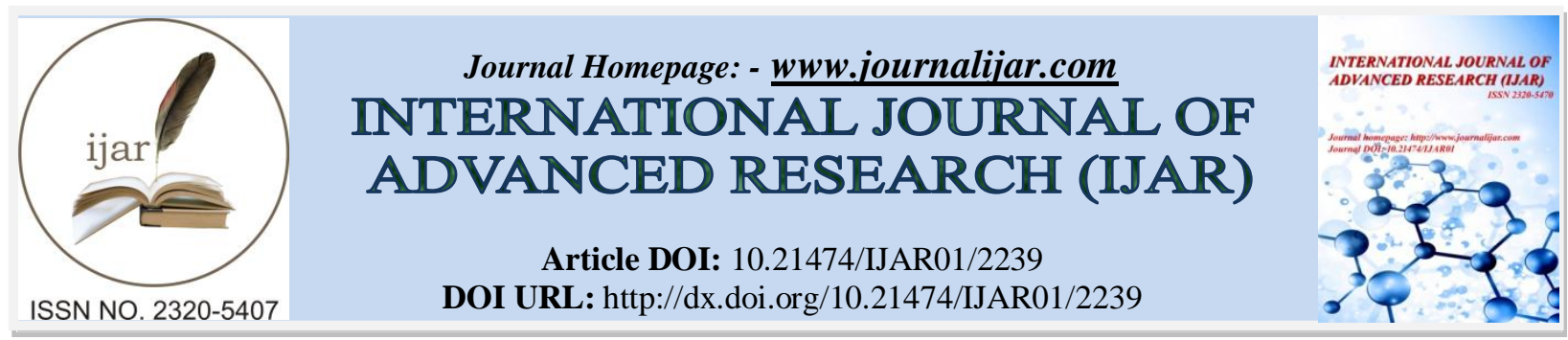

RESEARCH ARTICLE

\title{
EXOGENOUS APPLICATION OF CALCIUM CHLORIDE INFLUENCES THE PHYSICO-CHEMICAL CHANGES IN SUGAR APPLES (ANNONA SQUAMOSA L.) FRUITS IN COLD STORAGE.
}

\author{
A. K. Vandana*, G. J. Suresha and R. H. Hanamant.
}

Department of Postharvest Technology, Kittur Rani Channamma College of Horticulture, University of Horticultural Sciences, Bagalkot, Arabhavi - 591218, Karnataka.

\section{Manuscript Info}

Manuscript History

Received: 29 September 2016

Final Accepted: 30 October 2016

Published: November 2016

Key words:-

\section{Abstract}

The physicochemical characteristics and shelf life of sugar apple fruits treated with control and calcium chloride $(3,6,9 \%)$ for 5 minutes were studied. All tested treatments indicated a significant delay in the change of weight loss, firmness, respiration rate, titrable acidity, total soluble solids, colour $\left(L^{*}, a^{*}, b^{*}\right)$, and organoleptic evaluation in sugar apple fruits of experimental set than that of the control set. Moreover, the physicochemical analysis of sugar apple fruits of experimental set revealed that it also contain higher amount of titratable acidity and firmness. The significant impact of treatment is found on the least physiological loss of weight in the order of fruits treated with $\mathrm{CaCl}_{2} 6 \%$. Hence, it could be concluded that post harvest chemical treatment with $6 \%$ of $\mathrm{CaCl}_{2}$ has the potential to maintain the firmness, prolong the storage life upto 12 days and preserve in cold storage of $13 \pm 1^{\circ} \mathrm{C}$ of valuable attributes of post harvest sugar apple, presumably because of its effect on inhibition of ripening and senescence processes.

Copy Right, IJAR, 2016,. All rights reserved.

\section{Introduction:-}

The most important commercial fruits of the family Annonaceae are cherimoya (Annona cherimola Mill.), sugar apple (Annona squamosa L.) and the hybrid atemoya (Annona cherimola x Annona squamosa). Tokunaga, T. A (2000) who reported that, sugar apple fruit has a short shelf life when stored at room temperatures, and it is characterized by rapid skin browning and softening. Batten, D. J. (1990), Taylor, J. E. et al., 1993, Wills, R. B. H. (1984 \& 1998) has explained, ripening of some tropical and sub-tropical fruits can be retarded by storage at lower temperatures; however, sugar apple is very sensitive to low temperatures, presenting chilling injury symptoms, typically peel blackening, flesh browning and loss of aroma and flavor. Freire-júnior, M. and Chitarra, A. B. (1999) reported that, Postharvest treatment of calcium chloride have attracted recent research interest as a promising new technique to maintain fruit quality during storage; which might be an alternative to disinfestations of fruit and could modify its response to other stresses. In particular, biotechnologists have shown increasing interest in the use of postharvest heat shock to alleviate chilling injury in various crops and also inhibit biochemical pathways involved in ripening and other biological processes in a number of fruits and vegetables. Factors that influence temperature responses include species, variety, cultivation methods, fruit size, morphology, physiological maturity, final temperature and duration of exposure at various temperatures and type of treatment.

Corresponding Author:- A. K. Vandana.

Address:- Department of Postharvest Technology, Kittur Rani Channamma College of Horticulture, University of Horticultural Sciences, Bagalkot, Arabhavi - 591218, Karnataka. 
Lester, G. E. and Grusak, M. A. (2000) has explained, calcium chloride has shown promise in quality retention of fruits and vegetables. Pre- and postharvest application of calcium may help to reduce senescence during commercial and retail storage of fruit, with no detrimental effect on consumer acceptance. According to Joyce, D. C. et al., (2001) calcium dips have been employed to improve firmness and extend the postharvest shelf life of a wide range of fruits and vegetables; the effectiveness of such treatments may be influenced by the combination of time and temperature. Increasing the calcium content can help to delay softening and decrease the incidence of physiological disorders. According to Poovaiah, B. W. (1986) calcium chloride has been reported to reduce the onset of ripening in sugar apple (Lima, C. L. C. 2000), avocado (Yuen, C. M. C. et al., 1994) and strawberry (Hernández-muñoz, P. 2006) but not in banana (Perera, A. N. and Karunaratne, A. M. 2002) or mango (Shorter, A. J. and Joyce, D. C. 1998, Joyce, D. C. et al., 2001). According to Lima, sugar apples treated with $\mathrm{CaCl}_{2}(6 \%)$ and stored at $16^{\circ} \mathrm{C}$ showed reduced weight loss, respiration rates, control of the peroxidase activity, and maintained higher firmness, as the biochemical processes of ripening were delayed. Joyce, D. C. et al., 2001 studied by treatment with $4 \%$ calcium chloride did not extend the shelf life of mangoes from four cultivars. In recent years, significant advances have been made in fruit storage by the use of $\mathrm{CaCl}_{2}$ dipping alone or combined with other treatments. The aim of the present study was to investigate the effects of postharvest treatment of dipping in 3,6 and $9 \%$ of aqueous $\mathrm{CaCl}_{2}$ on the storage of sugar apple at $13 \pm 1^{\circ} \mathrm{C}$ with $85 \% \mathrm{RH}$ in cold storage.

\section{Materials and Methods:-}

Fruits of uniform size, shape and maturity were harvested in the evening and brought to the laboratory of the Department of Post Harvest Technology in plastic crates. The damaged, bruised, punctured and infected fruits were discarded manually. Then, the healthy fruits were pre-cooled in cold storage at $13 \pm 1^{\circ} \mathrm{C}$ for twelve hours to remove field heat. After removal from the cold room, fruits were thoroughly washed in 0.2 per cent sodium hypochlorite solution for five minutes to remove the surface microbial load and dirt adhered to the fruit surface. Immediately, fruits were air dried under fan to remove the surface moisture. These fruits were then used for further experimentation to impose different postharvest treatments to study their influence on behaviour and shelf life during storage.

The fruits were divided into four lots of 64 fruits with 16 fruits for each replication, the $T_{1}$ being control, the $T_{2}$ calcium chloride (3\%), the $\mathrm{T}_{3}$ with calcium chloride $(6 \%)$ and the $\mathrm{T}_{4}$ calcium chloride (9\%) for 5 minutes. After subjecting to dipping for specific duration in the respective treatment, custard apple fruits were surface dried under electric fan. Then the fruits were packed in ventilated corrugated fiber board (CFB) boxes. Paper lining was provided between the two layers of the fruits and paper shreds were used to provide cushioning and avoid fruits directly coming in contact with each other.

\section{Physiological parameters:- \\ Physiological loss in weight (PLW \%):-}

In each replication, 4 fruits were ear marked to record the PLW. The marked fruits in each replication of the respective treatment were weighed individually at the beginning of storage to record the initial weight. On subsequent days of observation, the fruits were weighed again. The cumulative losses in weight of fruits were calculated and expressed as per cent physiological loss in weight.

\section{Firmness (g):-}

Firmness of custard apple flesh was measured on 4 sides of the fruit at regular intervals taking a fruit from each replication by using force guage (Make: Lutron FG-5000A). It was recorded in Newton.

\section{Respiration rate $(\mathrm{ml} \mathrm{CO} / \mathrm{kg} / \mathrm{h}):-$}

Respiration rate was measured with a $\mathrm{CO}_{2}$ gas analyzer (Make: PBI Dansensor, CheckMate - II) in static method. The fruit was weighed and placed in a hermetically sealed container of $1250 \mathrm{ml}$ capacity for 60 minutes. At the end of incubation period, gas sample was drawn from the container head space using gas tight syringe and injected into the $\mathrm{CO}_{2}$ analyzer. The change in $\mathrm{CO}_{2}$ gas concentration in the head space and time was read in the instrument was recorded. The respiration rate of the fruit was expressed as $\mathrm{ml} \mathrm{CO}_{2} / \mathrm{kg} / \mathrm{h}$.

\section{Colour $\left(L^{*}, C^{*}\right.$ and $h^{o}$ angle):-}

The colour of the samples was measured using a Lovibond colour meter (Lovibond RT300, Portable spectrophotometer, The Tintometer Limited, Salisbury, UK) fitted with $8 \mathrm{~mm}$ diameter aperture and the instrument 
was adjusted at $10^{\circ}$ observer and D65 primary illuminant. The instrument was calibrated using the black and white tiles provided. Colour was expressed in Lovibond units $L^{*}$ (Lightness/darkness), $C^{*}$ (chroma) and $h^{o}$ angle (hue). Custard apple fruits were directly placed under the aperture of the colour meter.

\section{Biochemical parameters:-}

TSS ( $\left.{ }^{\mathbf{0}} \mathbf{B}\right)$ :-

The juice extracted by squeezing the homogenized fruit pulp through muslin cloth was used to measure the TSS. It was determined by using ERMA hand refractrometer, replicated four times and the mean was expressed in ${ }^{\circ} \mathrm{B}$.

Titratable acidity (\%):-

A known volume of juice sample $(10 \mathrm{ml})$ was taken and titrated against standard $\mathrm{NaOH}$ using phenolphthalein indicator. The appearance of light pink colour was marked as the end point. The value was expressed in terms of per cent titratable acidity of juice.

\section{Statistical analysis:-}

Statistical analysis was performed using Web Agri Stat Package (WASP) Version 2.0. All data the collected were analysed by one-way analysis of variance (ANOVA). Significant differences among means at $P \leq 0.05$ were determined by post hoc tests using Duncan's multiple range test.

\section{Results and Discussion:-}

Physiological loss in weight (PLW \%):-

Results on effect of $\mathrm{CaCl}_{2}$ on weight loss indicated significant differences. All the treatments involving $\mathrm{CaCl}_{2}$ were able to reduce the PLW significantly when compared to control. However, the treatment involving $\mathrm{CaCl}_{2}$ at 9 per cent effectively reduced the PLW $(8.28 \pm 0.48,10.42 \pm 0.29$ and $15.25 \pm 0.96$ per cent at 4,8 and 12 days, respectively) during the storage at $13 \pm 1^{\circ} \mathrm{C}$ and $80-85 \% \mathrm{RH}$.

Table 1:- Influence of calcium chloride dip treatments on physiological loss in weight of sugar apple fruits under cold storage $\left(13 \pm 1{ }^{\circ} \mathrm{C}\right.$ and 85 per cent $\left.\mathrm{RH}\right)$. Similar alphabets within the column represents non-significant differences at $(\mathrm{p}=0.05)$ probability level according into Duncan's multiple range test

\begin{tabular}{|l|l|l|l|}
\hline \multirow{2}{*}{ Treatments } & \multicolumn{3}{c|}{ Physiological loss of weight } \\
\cline { 2 - 4 } & \multicolumn{3}{|c|}{ Storage period (Days) } \\
\cline { 2 - 4 } & $\mathbf{4}$ & $\mathbf{8}$ & $\mathbf{1 2}$ \\
\hline $\mathrm{T}_{1}-$ Control & $13.02 \pm 2.15^{\mathbf{a}}$ & $25.12 \pm 5.54^{\mathbf{a}}$ & $30.67 \pm 5.06^{\mathbf{a}}$ \\
\hline $\mathrm{T}_{2}-$ Calcium chloride 3\% & $10.57 \pm 0.09^{\mathbf{b}}$ & $14.27 \pm 1.81^{\mathbf{b}}$ & $16.20 \pm 1.33^{\mathbf{b}}$ \\
\hline $\mathrm{T}_{3}-$ Calcium chloride 6\% & $9.30 \pm 0.23^{\mathbf{b}}$ & $11.42 \pm 1.12^{\mathbf{b}}$ & $14.33 \pm 1.39^{\mathbf{b}}$ \\
\hline $\mathrm{T}_{4}-$ Calcium chloride 9\% & $8.28 \pm 0.48^{\mathbf{c}}$ & $10.42 \pm 0.29^{\mathbf{b}}$ & $15.25 \pm 0.96^{\mathbf{b}}$ \\
\hline Mean & $\mathbf{1 0 . 2 9}$ & $\mathbf{1 5 . 3 0}$ & $\mathbf{1 9 . 1 1}^{\mathbf{3}}$ \\
\hline SEM \pm & 0.61 & 1.49 & 1.37 \\
\hline CD at 5\% & 1.89 & 4.58 & 4.23 \\
\hline
\end{tabular}

Initial value of physiological loss of weight is zero

\section{Firmness (g):-}

Fruit firmness $(\mathrm{N})$ was highest in the treatment with 9 per cent $\mathrm{CaCl}_{2}\left(\mathrm{~T}_{4}\right)$ throughout the storage period recording $4.0 \pm 0.0,3.85 \pm 0.04$ and $3.76 \pm 0.06 \mathrm{~N}$ at 4,8 and 12 days, respectively. Firmness in the untreated fruits declined rapidly recording $3.13 \pm 0.10,2.66 \pm 0.25$ and $1.77 \pm 0.51 \mathrm{~N}$ at 4,8 and 12 days, respectively during the study period leading to softness of the fruits.

Table 2:- Influence of calcium chloride dip treatments on firmness of sugar apple fruits under cold storage $\left(13 \pm 1^{\circ} \mathrm{C}\right.$ and 85 per cent $\mathrm{RH})$. Similar alphabets within the column represents non-significant differences at $(\mathrm{p}=0.05)$ probability level according into Duncan's multiple range test

\begin{tabular}{|l|l|l|l|}
\hline \multirow{2}{*}{ Treatments } & \multicolumn{3}{|c|}{ Firmness (N) } \\
\cline { 2 - 4 } & \multicolumn{3}{|c|}{ Storage period (Days) } \\
\cline { 2 - 4 } & $\mathbf{4}$ & $\mathbf{8}$ & $\mathbf{1 2}$ \\
\hline $\mathrm{T}_{1}-$ Control & $3.13 \pm 0.10^{\mathrm{d}}$ & $2.66 \pm 0.25^{\mathbf{c}}$ & $1.77 \pm 0.51^{\mathbf{c}}$ \\
\hline $\mathrm{T}_{2}-$ Calcium chloride 3\% & $3.64 \pm 0.12^{\mathbf{c}}$ & $3.34 \pm 0.18^{\mathbf{b}}$ & $2.81 \pm 0.40^{\mathbf{b}}$ \\
\hline
\end{tabular}




\begin{tabular}{|l|l|l|l|}
\hline $\mathrm{T}_{3}-$ Calcium chloride $6 \%$ & $3.81 \pm 0.11^{\mathbf{b}}$ & $3.60 \pm 0.29^{\mathbf{a b}}$ & $2.98 \pm 0.50^{\mathbf{b}}$ \\
\hline $\mathrm{T}_{4}-$ Calcium chloride $9 \%$ & $4.00 \pm 0.00^{\mathrm{a}}$ & $3.85 \pm 0.04^{\mathrm{a}}$ & $3.76 \pm 0.06^{\mathbf{a}}$ \\
\hline Mean & $\mathbf{3 . 6 5}$ & $\mathbf{3 . 3 6}$ & $\mathbf{2 . 8 3}$ \\
\hline SEM \pm & 0.50 & 0.10 & 0.20 \\
\hline CD at $5 \%$ & 0.15 & 0.32 & 0.63 \\
\hline
\end{tabular}

Initial value of firmness is $4.1 \mathrm{~N}$

\section{Respiration rate $(\mathrm{ml} \mathrm{CO} / \mathrm{kg} / \mathrm{h})$ :-}

Dip treatment of sugar apple fruits with all the three concentrations of $\mathrm{CaCl}_{2}$ used for the study significantly delayed the respiration rate compared to control throughout the storage $13 \pm 1^{\circ} \mathrm{C}$ and $80-85 \% \mathrm{RH}$. Untreated fruits recorded maximum respiration rates of $27.00 \pm 4.76,31.41 \pm 4.83$ and $34.75 \pm 3.40$ at 4,8 and 12 days, respectively. While, 9 per cent treated fruits registering $21.48 \pm 3.80,24.25 \pm 1.71$ and $25.38 \pm 0.75$ at 4,8 and 12 days, respectively.

Table 3:- Influence of calcium chloride dip treatments on respiration rate of sugar apple fruits under cold storage $\left(13 \pm 1{ }^{\circ} \mathrm{C}\right.$ and 85 per cent $\left.\mathrm{RH}\right)$. Similar alphabets within the column represents non-significant differences at $(\mathrm{p}=0.05)$ probability level according into Duncan's multiple range test

\begin{tabular}{|l|l|l|l|}
\hline \multirow{2}{*}{ Treatments } & \multicolumn{3}{|c|}{ Respiration rate $\left(\mathrm{ml} \mathrm{CO}_{2} / \mathrm{Kg} / \mathrm{h}\right)$} \\
\cline { 2 - 4 } & \multicolumn{3}{|c|}{ Storage period (Days) } \\
\cline { 2 - 4 } & $\mathbf{4}$ & $\mathbf{8}$ & $\mathbf{1 2}$ \\
\hline $\mathrm{T}_{1}-$ Control & $27.00 \pm 4.76^{\mathbf{a}}$ & $31.41 \pm 4.83^{\mathbf{a}}$ & $34.75 \pm 3.40^{\mathbf{a}}$ \\
\hline $\mathrm{T}_{2}-$ Calcium chloride $\%$ & $21.58 \pm 1.91^{\mathbf{b}}$ & $24.35 \pm 2.41^{\mathbf{b}}$ & $27.00 \pm 1.83^{\mathbf{b}}$ \\
\hline $\mathrm{T}_{3}-$ Calcium chloride $\%$ & $20.31 \pm 0.23^{\mathbf{b}}$ & $25.98 \pm 3.42^{\mathbf{b}}$ & $26.75 \pm 3.86^{\mathbf{b}}$ \\
\hline $\mathrm{T}_{4}-$ Calcium chloride $9 \%$ & $21.48 \pm 3.80^{\mathbf{b}}$ & $24.25 \pm 1.71^{\mathbf{b}}$ & $25.38 \pm 0.75^{\mathbf{b}}$ \\
\hline Mean & $\mathbf{2 2 . 5 9}$ & $\mathbf{2 6 . 4 9}$ & $\mathbf{2 8 . 4 7}$ \\
\hline SEM \pm & 1.60 & 1.65 & 1.38 \\
\hline CD at 5\% & 4.93 & 5.09 & 4.24 \\
\hline
\end{tabular}

Initial value of respiration rate is $18.13 \mathrm{ml} \mathrm{CO} / \mathrm{Kg} / \mathrm{h}$

Colour ( $L^{*}, c^{*}$ and $h^{o}$ angle):-

Luminosity $\left(L^{*}\right)$ values:-

Lightness $\left(L^{*}\right)$ values of custard apple peel decreased with the advancement in storage period. Custard apple fruits treated with $\mathrm{CaCl}_{2}$ registered slower declining of $L^{*}$ values when comparing with untreated fruits which undergone rapid changes (Table 1). Fruits dipped in $\mathrm{CaCl}_{2}$ solution registered significant differences with untreated fruits $(\mathrm{p}<0.05)$. Calcium chloride at 6 per cent treated fruits recorded higher values $(72.25 \pm 1.71)$ which were on par with 9 per cent $\mathrm{CaCl}_{2}$ treated fruits $(71.00 \pm 1.83)$ at 12 days of storage at $13 \pm 1^{\circ} \mathrm{C}$ and $80-85 \% \mathrm{RH}$.

Table 4:- Influence of calcium chloride dip treatments on color $\left(L^{*}\right)$ of sugar apple fruits under cold storage $\left(13 \pm 1^{\circ} \mathrm{C}\right.$ and 85 per cent $\left.\mathrm{RH}\right)$. Similar alphabets within the column represents non-significant differences at $(\mathrm{p}=0.05)$ probability level according into Duncan's multiple range test

\begin{tabular}{|l|l|l|l|}
\hline \multirow{2}{*}{ Treatments } & \multicolumn{3}{|c|}{ Lightness $\left(L^{*}\right)$} \\
\cline { 2 - 4 } & \multicolumn{3}{|c|}{ Storage period (Days) } \\
\cline { 2 - 4 } & $\mathbf{4}$ & $\mathbf{8}$ & $\mathbf{1 2}$ \\
\hline $\mathrm{T}_{1}-$ Control & $76.25 \pm 1.26^{\mathbf{b}}$ & $64.18 \pm 5.67^{\mathbf{b}}$ & $44.84 \pm 2.13^{\mathbf{b}}$ \\
\hline $\mathrm{T}_{2}-$ Calcium chloride 3\% & $79.99 \pm 0.18^{\mathbf{a}}$ & $74.60 \pm 2.41^{\mathbf{a}}$ & $45.95 \pm 7.73^{\mathbf{b}}$ \\
\hline $\mathrm{T}_{3}-$ Calcium chloride 6\% & $79.12 \pm 0.19^{\mathbf{a}}$ & $75.68 \pm 1.52^{\mathbf{a}}$ & $72.25 \pm 1.71^{\mathbf{a}}$ \\
\hline $\mathrm{T}_{4}-$ Calcium chloride $9 \%$ & $79.99 \pm 0.15^{\mathbf{a}}$ & $74.27 \pm 2.00^{\mathbf{a}}$ & $71.00 \pm 1.83^{\mathbf{a}}$ \\
\hline Mean & $\mathbf{7 8 . 8 3}$ & $\mathbf{7 2 . 1 8}$ & $\mathbf{5 8 . 5 1}$ \\
\hline SEM \pm & 0.32 & 1.66 & 2.10 \\
\hline CD at 5\% & 0.99 & 5.13 & 6.47 \\
\hline
\end{tabular}

Initial value of lightness $\left(L^{*}\right)$ is 84.42

\section{Saturation/Chroma $\left(C^{*}\right)$ values:-}

Chroma values of peel of custard apples increased from initial 7.08 to 17.98 at the end of 12 days at $13 \pm 1^{\circ} \mathrm{C}$ and 80 $85 \% \mathrm{RH}$ (Table 1). Dip treatment of $\mathrm{CaCl}_{2}$ significantly differed with uncoated fruits $(\mathrm{p}<0.05)$. Uncoated fruits 
recorded higher values for $C^{*}(9.58 \pm 2.17,14.93 \pm 2.73$ and $21.47 \pm 2.14$ at 4,8 and 12 days, respectively) while, 9 $\% \mathrm{CaCl}_{2}$ treated fruits recorded lower change in $C^{*}$ values $(7.30 \pm 0.15,11.44 \pm 0.97$ and $15.69 \pm 1.90$ at 4,8 and 12 days, respectively).

Table 5:- Influence of calcium chloride dip treatments on color $\left(c^{*}\right)$ of sugar apple fruits under cold storage (13 \pm 1 ${ }^{\circ} \mathrm{C}$ and 85 per cent $\left.\mathrm{RH}\right)$. Similar alphabets within the column represents non-significant differences at $(\mathrm{p}=0.05)$ probability level according into Duncan's multiple range test

\begin{tabular}{|c|c|c|c|}
\hline \multirow{3}{*}{ Treatments } & \multicolumn{3}{|c|}{ Chroma $\left(C^{*}\right)$} \\
\hline & \multicolumn{3}{|c|}{ Storage period (Days) } \\
\hline & 4 & 8 & 12 \\
\hline $\mathrm{T}_{1}-$ Control & $9.58 \pm 2.17^{\mathrm{a}}$ & $14.93 \pm 2.73^{\mathrm{a}}$ & $21.47 \pm 2.14^{\mathrm{a}}$ \\
\hline $\mathrm{T}_{2}-$ Calcium chloride $3 \%$ & $7.29 \pm 0.16^{b}$ & $12.69 \pm 0.98^{\mathrm{ab}}$ & $18.71 \pm 2.66^{\mathrm{ab}}$ \\
\hline $\mathrm{T}_{3}-$ Calcium chloride $6 \%$ & $7.27 \pm 0.11^{b}$ & $10.82 \pm 1.53^{b}$ & $16.06 \pm 3.41^{b}$ \\
\hline $\mathrm{T}_{4}-$ Calcium chloride $9 \%$ & $7.30 \pm 0.15^{\mathrm{b}}$ & $11.44 \pm 0.97^{b}$ & $15.69 \pm 1.90^{\mathrm{b}}$ \\
\hline Mean & 7.86 & 12.47 & 17.98 \\
\hline SEM \pm & 0.54 & 0.85 & 1.30 \\
\hline $\mathrm{CD}$ at $5 \%$ & 1.68 & 2.63 & 4.00 \\
\hline
\end{tabular}

Initial value of chroma $\left(C^{*}\right)$ is 7.08

Hue $\left(h^{\circ}\right)$ angle:-

Hue angle of custard apple fruits treated with $\mathrm{CaCl}_{2}$ decreased from initial 80 to 71.94 during storage at 12 days at $13 \pm 1^{\circ} \mathrm{C}$ (Table 1). Untreated fruits showed rapid decline in $h^{\circ}$ and recorded least values $(76.26 \pm 0.77,71.95 \pm 1.37$ and $65.77 \pm 3.50$ at 4,8 and 12 days, respectively).

Table 6:- Influence of calcium chloride dip treatments on color $\left(h^{o}\right)$ of sugar apple fruits under cold storage $(13 \pm 1$ ${ }^{\circ} \mathrm{C}$ and 85 per cent $\left.\mathrm{RH}\right)$. Similar alphabets within the column represents non-significant differences at $(\mathrm{p}=0.05)$ probability level according into Duncan's multiple range test.

\begin{tabular}{|l|l|l|l|}
\hline \multirow{2}{*}{ Treatments } & \multicolumn{3}{|c|}{ Hue $\left(h^{\circ}\right)$} \\
\cline { 2 - 4 } & \multicolumn{3}{|c|}{ Storage period (Days) } \\
\cline { 2 - 4 } & $\mathbf{4}$ & $\mathbf{8}$ & $\mathbf{1 2}$ \\
\hline $\mathrm{T}_{1}-$ Control & $76.26 \pm 0.77^{\mathbf{b}}$ & $71.95 \pm 1.37^{\mathbf{b}}$ & $65.77 \pm 3.50^{\mathbf{c}}$ \\
\hline $\mathrm{T}_{2}-$ Calcium chloride 3\% & $77.25 \pm 0.50^{\mathbf{a b}}$ & $73.75 \pm 1.26^{\mathbf{b}}$ & $70.10 \pm 1.77^{\mathbf{b}}$ \\
\hline $\mathrm{T}_{3}-$ Calcium chloride $\%$ & $78.28 \pm 0.84^{\mathbf{a}}$ & $76.31 \pm 1.10^{\mathbf{a}}$ & $75.61 \pm 1.13^{\mathbf{a}}$ \\
\hline $\mathrm{T}_{4}-$ Calcium chloride $9 \%$ & $78.00 \pm 0.82^{\mathbf{a}}$ & $77.30 \pm 0.90^{\mathbf{a}}$ & $76.29 \pm 1.33^{\mathbf{a}}$ \\
\hline Mean & $\mathbf{7 7 . 4 5}$ & $\mathbf{7 4 . 8 3}$ & $\mathbf{7 1 . 9 4}$ \\
\hline $\mathrm{SEM} \pm$ & 0.37 & 0.58 & 1.07 \\
\hline CD at 5\% & 1.15 & 1.80 & 3.30 \\
\hline
\end{tabular}

Initial value of hue $\left(h^{o}\right)$ angle is 80:-

Lower alteration or higher retention of peel $C^{*}$ and $\mathrm{h}^{\circ}$ values were noticed in the treatments involving $\mathrm{CaCl}_{2}$. The fact that calcium treatments reduce the respiration rate and delay fruit ripening (Faust and Shear, 1971a) is attributed to the effect of calcium in cytosol is regulation of respiratory activity. The fruit with less calcium content has a very high respiratory rate and the respiration rate is inversely related to calcium concentration (Faust and Shear, 1971b). Calcium concentration in the tissue cell wall directly influences the production of $\mathrm{CO}_{2}$ and ethylene (Conway and Sams, 1987). Calcium chloride treatment of 9 per cent retained higher peel and pulp $h^{\circ}$ and $C^{*}$ values during 14 days at cold storage. This might be due to increased accumulation of calcium in the cell wall and middle lamella and also due to binding of calcium ions with protein molecules. As a result, the prevention of green pigment degradation that might have persisted during prolonged storage in cold storage. These findings are corroborate the works of Lima (2000) who reported dip treatment of sugar apples had a positive effect on delaying biochemical and physiological processes leading to ripening. In our study, minimum change in the peel and pulp color values may be attributed to the positive effect of calcium in delaying of flesh browning. The results support the earlier works of Torres et al. (2009) on 'Gefner' attemoya. Other researchers also reported the beneficial effects of calcium dip treatments post harvest in delaying the color change during low temperature storage on different other crops such as in fig (Irfan et al. 2013), in passion fruit (Silva and Vieites, 2000). 


\section{TSS $\left({ }^{0} \mathbf{B}\right):-$}

Results on soluble solids indicated untreated custard apple fruits recorded maximum values on $4^{\text {th }}(12.50 \pm 0.58), 8^{\text {th }}$ $(14.13 \pm 0.85)$ and $12^{\text {th }}(19.75 \pm 0.50)$ days which was significantly differing with $\mathrm{CaCl}_{2}$ treatments. Fruits treated with 9 per cent $\mathrm{CaCl}_{2}$ registered minimum soluble solids $(17.00 \pm 0.82)$ which was on par with fruits received 6 per cent $\mathrm{CaCl} 2(17.75 \pm 0.5)$ at 12 days of storage at $13 \pm 1^{\circ} \mathrm{C}$ and $80-85 \% \mathrm{RH}$.

Table 7:- Influence of calcium chloride dip treatments on total soluble solids of sugar apple fruits under cold storage $\left(13 \pm 1{ }^{\circ} \mathrm{C}\right.$ and 85 per cent $\left.\mathrm{RH}\right)$. Similar alphabets within the column represents non-significant differences at $(\mathrm{p}=0.05)$ probability level according into Duncan's multiple range test.

\begin{tabular}{|c|c|c|c|}
\hline \multirow[t]{3}{*}{ Treatments } & \multicolumn{3}{|c|}{ Total soluble solids $\left({ }^{\circ} \mathrm{B}\right)$} \\
\hline & \multicolumn{3}{|c|}{ Storage period (Days) } \\
\hline & 4 & 8 & 12 \\
\hline $\mathrm{T}_{1}-$ Control & $12.50 \pm 0.58^{\mathrm{a}}$ & $14.13 \pm 0.85^{\mathrm{a}}$ & $19.75 \pm 0.50^{\mathrm{a}}$ \\
\hline $\mathrm{T}_{2}-$ Calcium chloride $3 \%$ & $11.75 \pm 0.65^{\mathbf{a b}}$ & $12.63 \pm 0.48^{\mathrm{b}}$ & $19.00 \pm 0.80^{\mathrm{a}}$ \\
\hline $\mathrm{T}_{3}-$ Calcium chloride $6 \%$ & $11.41 \pm 0.45^{b}$ & $12.32 \pm 0.38^{\mathbf{b}}$ & $17.75 \pm 0.50^{\mathrm{b}}$ \\
\hline $\mathrm{T}_{4}-$ Calcium chloride $9 \%$ & $11.50 \pm 0.41^{\mathbf{b}}$ & $12.38 \pm 0.48^{\mathrm{b}}$ & $17.00 \pm 0.82^{\mathrm{b}}$ \\
\hline Mean & 11.79 & 12.87 & 18.38 \\
\hline SEM \pm & 0.27 & 0.29 & 0.34 \\
\hline CD at $5 \%$ & 0.82 & 0.89 & 1.04 \\
\hline
\end{tabular}

Initial value of total soluble solid is $11^{\circ} \mathrm{B}$

Tritratable Acidity (\%):-

Rapid reduction of TA was noticed in the untreated custard apple fruits at $4^{\text {th }}(0.28 \pm 0.02), 8^{\text {th }}(0.23 \pm 0.02)$ and $12^{\text {th }}$ $(0.19 \pm 0.02)$ during the storage. Significantly slower and progressive decline was recorded in the fruits treated with 9 per cent $\mathrm{CaCl}_{2}(0.34 \pm 0.02,0.31 \pm 0.01$ and $0.30 \pm 0.01$ at 4,8 and 12 days, respectively).

Table 8:- Influence of calcium chloride dip treatments on titratable acidity of sugar apple fruits under cold storage $\left(13 \pm 1{ }^{\circ} \mathrm{C}\right.$ and 85 per cent $\left.\mathrm{RH}\right)$. Similar alphabets within the column represents non-significant differences at $(\mathrm{p}=0.05)$ probability level according into Duncan's multiple range test

\begin{tabular}{|l|l|l|l|}
\hline \multirow{2}{*}{ Treatments } & \multicolumn{3}{|c|}{ Titratable acidity (\%) } \\
\cline { 2 - 4 } & \multicolumn{3}{|c|}{ Storage period (Days) } \\
\cline { 2 - 4 } & $\mathbf{4}$ & $\mathbf{8}$ & $\mathbf{1 2}$ \\
\hline $\mathrm{T}_{1}-$ Control & $0.28 \pm 0.02^{\mathbf{c}}$ & $0.23 \pm 0.02^{\mathbf{b}}$ & $0.19 \pm 0.02^{\mathbf{c}}$ \\
\hline $\mathrm{T}_{2}-$ Calcium chloride 3\% & $0.31 \pm 0.01^{\mathbf{b}}$ & $0.30 \pm 0.02^{\mathbf{a}}$ & $0.25 \pm 0.03^{\mathbf{b}}$ \\
\hline $\mathrm{T}_{3}$-Calcium chloride $6 \%$ & $0.35 \pm 0.01^{\mathbf{a}}$ & $0.32 \pm 0.01^{\mathbf{a}}$ & $0.29 \pm 0.02^{\mathbf{a}}$ \\
\hline $\mathrm{T}_{4}-$ Calcium chloride $9 \%$ & $0.34 \pm 0.02^{\mathbf{a}}$ & $0.31 \pm 0.01^{\mathbf{a}}$ & $0.30 \pm 0.01^{\mathbf{a}}$ \\
\hline Mean & $\mathbf{0 . 3 2}$ & $\mathbf{0 . 2 9}$ & $\mathbf{0 . 2 5}$ \\
\hline $\mathrm{SEM} \pm$ & 0.01 & 0.01 & 0.01 \\
\hline CD at 5\% & 0.02 & 0.02 & 0.03 \\
\hline
\end{tabular}

Initial value of titratable acidity is $0.36 \%$

Phenols (\%):-

Results pertaining to phenol concentration showed significant differences $(\mathrm{p}<0.05)$ with untreated and $\mathrm{CaCl}_{2}$ treated fruits. Sugar apple fruits treated with 9 per cent $\mathrm{CaCl}_{2}$ registered maximum phenols $(2.23 \pm 0.06,2.18 \pm 0.03$ and $2.18 \pm 0.02$ at 4,8 and 12 days, respectively) during the storage and which was on par with 6 per cent treatment throughout the storage.

Table 9:- Influence of calcium chloride dip treatments on phenols of sugar apple fruits under cold storage $\left(13 \pm 1{ }^{\circ} \mathrm{C}\right.$ and 85 per cent $\mathrm{RH})$. Similar alphabets within the column represents non-significant differences at $(\mathrm{p}=0.05)$ probability level according into Duncan's multiple range test.

\begin{tabular}{|l|l|l|l|}
\hline \multirow{2}{*}{ Treatments } & \multicolumn{3}{|c|}{ Phenols (\%) } \\
\cline { 2 - 4 } & \multicolumn{3}{|c|}{ Storage period (Days) } \\
\cline { 2 - 4 } & $\mathbf{4}$ & $\mathbf{8}$ & $\mathbf{1 2}$ \\
\hline $\mathrm{T}_{1}-$ Control & $2.04 \pm 0.08^{\mathbf{c}}$ & $1.83 \pm 0.02^{\mathbf{c}}$ & $1.47 \pm 0.03^{\mathbf{c}}$ \\
\hline $\mathrm{T}_{2}-$ Calcium chloride $3 \%$ & $2.13 \pm 0.02^{\mathbf{b c}}$ & $2.08 \pm 0.02^{\mathbf{b}}$ & $1.97 \pm 0.03^{\mathbf{b}}$ \\
\hline
\end{tabular}




\begin{tabular}{|l|l|l|l|}
\hline $\mathrm{T}_{3}-$ Calcium chloride $6 \%$ & $2.19 \pm 0.01^{\mathrm{ab}}$ & $2.18 \pm 0.01^{\mathrm{a}}$ & $2.16 \pm 0.02^{\mathrm{a}}$ \\
\hline $\mathrm{T}_{4}-$ Calcium chloride $\% \%$ & $2.23 \pm 0.06^{\mathrm{a}}$ & $2.18 \pm 0.03^{\mathrm{a}}$ & $2.18 \pm 0.02^{\mathrm{a}}$ \\
\hline Mean & $\mathbf{2 . 1 5}$ & $\mathbf{2 . 0 7}$ & $\mathbf{1 . 9 4}$ \\
\hline SEM \pm & 0.04 & 0.01 & 0.02 \\
\hline CD at $5 \%$ & 0.08 & 0.03 & 0.04 \\
\hline
\end{tabular}

Initial value of phenol is $2.31 \%$

\section{References:-}

1. Batten, D. J. 1990. Effect of temperature on ripening and postharvest life of fruit of atemoya (Annona cherimola Mill. X A. squamosa L.) cv. 'African Pride'. Sci. Hortic., (45): 129-136.

2. Conway, W. S. and Sams, C. E. 1987. The effects of postharvest infiltration of calcium, magnesium, or strontium on decay, firmness, respiration, and ethylene production in apples. J. Amer. Soc. Hort. Sci. 112:300303.

3. Freire-júnior, M. and Chitarra, A. B. 1999. Efeito da aplicação do cloreto de cálcio nos frutos da manga 'Tommy Atkins' tratados hidrotermicamente. Pesqui. Agropec. Bras., 5(34):761-769.

4. Hernández-muñoz, P. 2006. Effect of calcium dips and chitosan coatings on postharvest life of strawberries (Fragaria x ananassa). Postharvest Biol. Technol., (39):247-253.

5. Irfan, P. K., Vanjakshi, V., Keshava Prakash, M. N., Ravi, R. and Kudachikar, V. B. 2013. Calcium chloride extends the keeping quality of fig fruit (Ficus carica L.) durig storage and shelf-life. Postharvest Biol. Tech. 82: $70-75$.

6. Joyce, D. C. Shorter, A. J. and Hockings, P. D. 2001. Mango fruit calcium levels and the effect of postharvest calcium infiltration at different maturities. Sci. Hortic., 91:81-99.

7. Joyce, D. C., Shorter, A. J. and Hockings, P. D. 2001. Mango fruit calcium levels and the effect of postharvest calcium infiltration at different maturities. Sci. Hortic., (91):81-99.

8. Lester, G. E. and Grusak, M. A. 2000. Postharvest application of chelated and nonchelated calcium dip treatments to commercially grown honey dew melons: effects on peel attribute tissue calcium concentration, quality, and consumer preference following storage. Hortic. Technol., (11):561-566.

9. Lima, C. I. C. 2000. Uso de ceras e do calico associados ou nao, na conservacao poscolheita de frutos da pinheira (Annona squamosa L.) armazenados ao ambiente ou sob refrigeracao. Tese. (Duotorado em Energia na agricultura) Botucatu; Faculdade de Ciencias Agronomica, Universidade Estadual Paulista. p. 119.

10. Lima, C. L. C. 2000. Uso de ceras e do cálcio, associados ou não, na conservação pós-colheita de frutos da pinheira (Annona squamosa L.) armazenados ao ambiente ou sob refrigeração.

11. Perera, A. N. and Karunaratne, A. M. 2002. Postharvest calcium chloride treatments do not help to increase shelf-life of bananas. Fruits, (57):87-94.

12. Poovaiah, B. W. 1986. Role of calcium in prolonging storage life of fruits and vegetables. Food Technol., 5(40):86-89.

13. Shear, C. B. Fraust, M. 1971, Don't neglect calcium in your apples tree's diet. American fruit grower 19(4):1820.

14. Shorter, A. J. and Joyce, D. C. 1998. Effect of partial pressure infiltration of calcium into 'Kensington' mango fruit. Aust. J. Exp. Agric., 38:287-294.

15. Silva, A. P. and Vieites, R. L. 2000. Changes in physical characteristics of the sweet passion fruit submitted to immersion in solution of calcium chloride. Ciencia e-Technologia-de-Alimentos. 20: 56-59.

16. Taylor, J. E., Seymour, G. B. and Tucker, G. A. 1993. Biochemistry of fruit ripening. London: Chapman \& Hall, 152-187.

17. Tokunaga, T. A. 2000. cultura da atemóia. Campinas: CATI,. 80p.

18. Torres, L. M. A. R., Silva, M. A., Guaglianoni, D. G. and Neves, V.A. 2009. Effect of heat treatment and calcium on postharvest storage of atemoya fruits. Alimentos e Nutricao Aranaquara. 20(3): 359-367.

19. Wills, R. B. H. 1984. Postharvest changes in fruit composition of Annona atemoya during ripening and effects of storage temperature on ripening. HortScience, (19):96-97.

20. Wills, R. B. H. 1998. Postharvest: an introduction to the physiology \& handling of fruit, vegetables \& ornamentals. Wallingford: UNSW, (4):262.

21. Yuen, C. M. C. Caffin, N. and Boonyakiat, D. 1994. Effect of calcium infiltration on ripening of avocados at different maturities. Aust. J. Exp. Agric., (34):123-126. 